\title{
Study and Application of Seismic Risk and Exposure Model Based on AI Technologies
}

\author{
Changlong $\mathrm{Li}^{*}$, Zongchao Li, Hongshan Lyu, Mengtan Gao
}

Institute of Geophysics, China Earthquake Administration

${ }^{*}$ Corresponding author. Email: changlongli@163.com

\begin{abstract}
This paper investigated the numbers, taxonomy and vulnerability of the buildings in Southeastern Tibet and built pattern classes for difference types of buildings. Then we assessed the distribution of each type of buildings in every town based on 3D image pattern recognition, and made an event-based and a 50-year hazard-based seismic risk assessment for the towns in Southeastern Tibet. Our study indicated that areas with the highest seismic risk are urban areas of Lhasa and Nyingchi and Cuona Town, and urban Lhasa has the highest seismic risk of building structural economic losses.
\end{abstract}

Keywords: Pattern Recognition, Seismic risk, Exposure

\section{基于人工智能技术的地震风险暴露度模型研究及应用}

李昌珑 ${ }^{*}$, 李宗超, 吕红山, 高孟潭

中国地震局地球物理研究所

*通讯作者。电子邮箱: changlongli@163. com

\section{摘要}

本文在对西藏东南部各县的建筑类型、数量、易损性调查的基础上，对不同类型的建筑建立了模式类向量， 使用三维图像模式识别技术估计了各类型建筑在西藏东南部各县市的数量分布，建立了不同建筑物的结构易 损性和人口易损性模型, 开展了西藏东南部的地震风险分析。本文研究表明, 西藏东南部未来 50 年建筑地震 风险最高的地区是拉萨市区、林芝市区和错那县，其中拉萨市区的建筑财产损失风险最高。

关键字：图像模式识别，地震风险，暴露度

\section{1. 引言}

图像模式识别 (Image Pattern Recognition) 技术是人工智能 (Artificial Intelligence, AI) 技术的重要分支, 是根据图像对象的特征建立模式 类, 并根据对象的模式取值, 确定对象的从属关系 的技术。图像模式识别已经在卫星图片、遥感等二 维图像处理研究中得到了较多应用 ${ }^{[1-3]}$ 。但是, 对图 像中三维特征的处理和识别技术还未在建筑结构类 型的统计中获得广泛应用。本文尝试将三维图像模 式识别技术应用在无人机航拍图像处理和模式识别
中, 用于建筑类型和数量的统计, 为 AI 技术在地学 研究中的更多应用进行探索。

西藏东南部包括拉萨、山南、林芝三市，共 27 个区县, 总人口约 200 万, 约占西藏人口的三分之 二, 是西藏人口最稠密、经济相对发达的地区。同 时，西藏东南部位于欧亚板块和印度板块边界，分 布有多条大型活动构造断裂，大地震频繁发生，地 震危险性较高 ${ }^{[4]}$ 。了解西藏东南部的地震风险具有 重要的意义。本文在对西藏东南部各县的建筑类型、 数量、易损性调查的基础上，结合当地的人口和住 
房特点，估计了不同类型建筑在西藏东南部的分布 情况，建立了不同建筑物的结构易损性和人口易损 性模型, 并且估算了西藏东南部各县在遭遇一次设 定地震时的损失分布和基于危险性的未来 50 年可能 的损失分布情况。

\section{2.人口数据}

西藏东南部人口分布数据来自第六次人口普查 和各县市的年度报告 ${ }^{\left[{ }^{[}\right]}$。可收集到的数据有每个县 的总人口和总户数, 以及城镇人口数和农村人口数。 西藏东南部各县人口数量如图 1 所示。

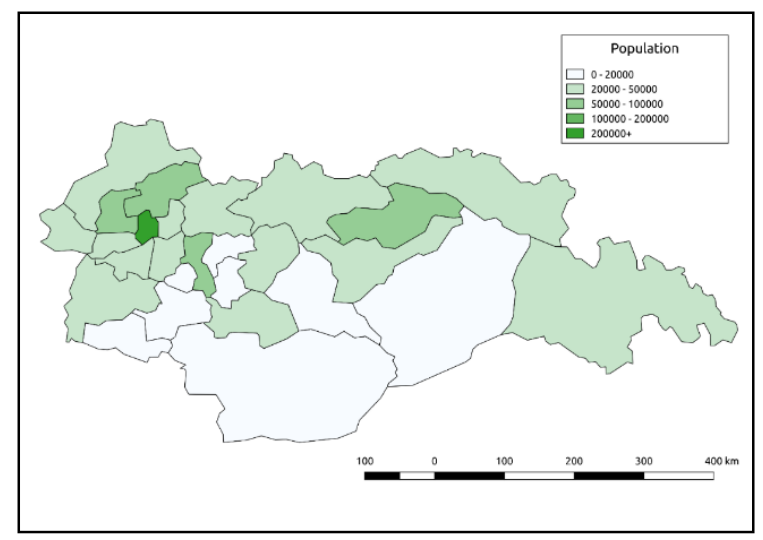

图 1 西藏东南部各县人口分布图（数据来源：第六次人 口普查）

\section{3. 建筑分类}

建筑的分类基于中国地震局地球物理研究所对西 藏东南部的实地考察。考察走访了西藏东南部 27 个 区县中的 13 个（图 1), 采集的建筑物样本超过一 千栋。考察中发现, 西藏东南部的建筑分布存在以 下几个特点:

（1）人口和建筑多分布于河谷, 集中于市区县城。

（2）民居的结构类型和易损性特征在卫星图片上 难识别, 但无人机航拍可识别。

（3）城镇居民和农村居民的房屋结构和易损性存 在差别, 城区楼房与内地城市差别不大, 农村分布 有较多自建新房和传统老旧藏式建筑。

（4）藏东南林区有相当数量的木结构房屋。

根据在西藏东南部的实地调查结果, 将西藏东南 部的建筑分为以下四类: 公建房 (PUB)、自建新 房（PRV）、老旧房（OLD）和木结构房（WOD）。 四种建筑的典型图如图 2 所示。
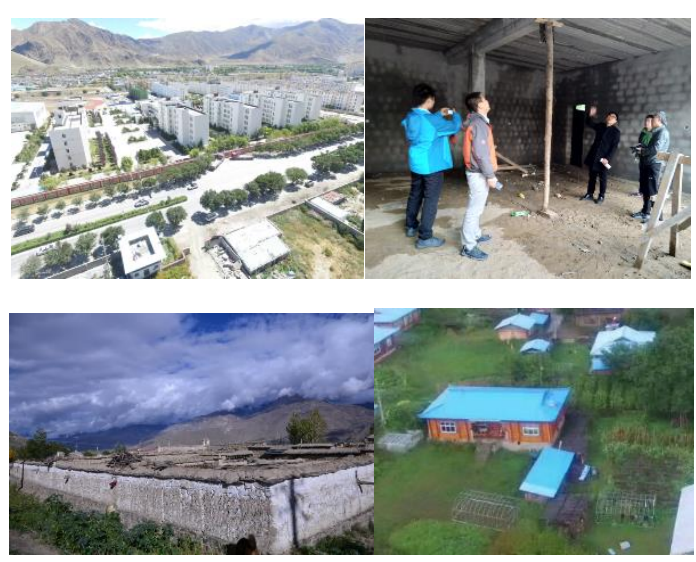

图 2 四种房屋建筑类型典型图 (上左: 公建房; 上右: 自建新房; 下左：老旧房; 下右：木结构。资料来源：中 国地震局地球物理研究所地震保险项目组）

4 类建筑结构的外观特征较为鲜明:

（1）公建房通常层数较多, 多不少于 3 层, 而其 他 3 类建筑很少超过 2 层。

（2）老旧房具有传统藏式建筑的特征, 开窗较小, 明显小于其他 3 类建筑。

（3）木结构建筑的外观有明显的由于木桩（板） 拼接形成的密集栅格状纹理。

这些特征可用于建立各类建筑的模式和模式类。

\section{4. 建筑类型模式类向量的建立和模式识别}

要对建筑的图像进行模式识别, 需要确定所考虑 的模式。通过对第 3 节四种建筑类型的特征分析, 考虑建筑的 3 个模式: 层数 (F) 、窗户面积比 (W) 和密集栅格状纹理（T)。3 个模式分别说明如下:

（1）层数 F：建筑的层数。该模式主要用于识别 出公建房。

（2）窗户面积比 W: 外墙窗户面积与墙面面积之 比。该模式主要用于识别出老旧传统藏式建筑。

（3）密集栅格状纹理 T: 外墙有密集栅格状纹理 记为 $\mathrm{T}=1$, 反之记为 $\mathrm{T}=0$ 。该模式主要用于识别出木 结构建筑。

3 个模式对应的模式类向量可表示为层数模式类 $\left(\mathrm{F}_{\mathrm{PUB}}, \mathrm{F}_{\mathrm{PRV}}, \mathrm{F}_{\mathrm{OLD}}, \mathrm{F}_{\mathrm{WOD}}\right)$ 、窗户面积比模式类 $\left(W_{\mathrm{PUB}}, \mathrm{W}_{\mathrm{PRV}}\right.$, $\left.W_{\text {OLD }}, W_{\text {wOD }}\right)$ 和栅格状纹理模式类 $\left(\mathrm{T}_{\mathrm{PUB}}, \mathrm{T}_{\mathrm{PRV}}, \mathrm{T}_{\text {OLD }}, \mathrm{T}_{\text {WOD }}\right)$ 。 模式识别的思想为, 将图像转换为像素信息矩阵; 在像素信息矩阵中识别出符合建筑矩阵特征的子矩 阵, 作为建筑单元并统计建筑数量; 以每幢建筑为 单位, 分别读取建筑图像模式 $F 、 W$ 和 $T$, 当 $F \geqslant 3$ 时 识别为 $P U B$; 当 $F<3$ 且 $W<0.1$ 是识别为 $0 L D$; 当 $F<3$ 且 $W \geqslant 0.1$ 且 $T=1$ 时识别为 WOD; 其余识别为 $P R V$ 。模 式识别的流程图如图 3 所示。对一幅图像的模式识 别示例如图 4 所示。 


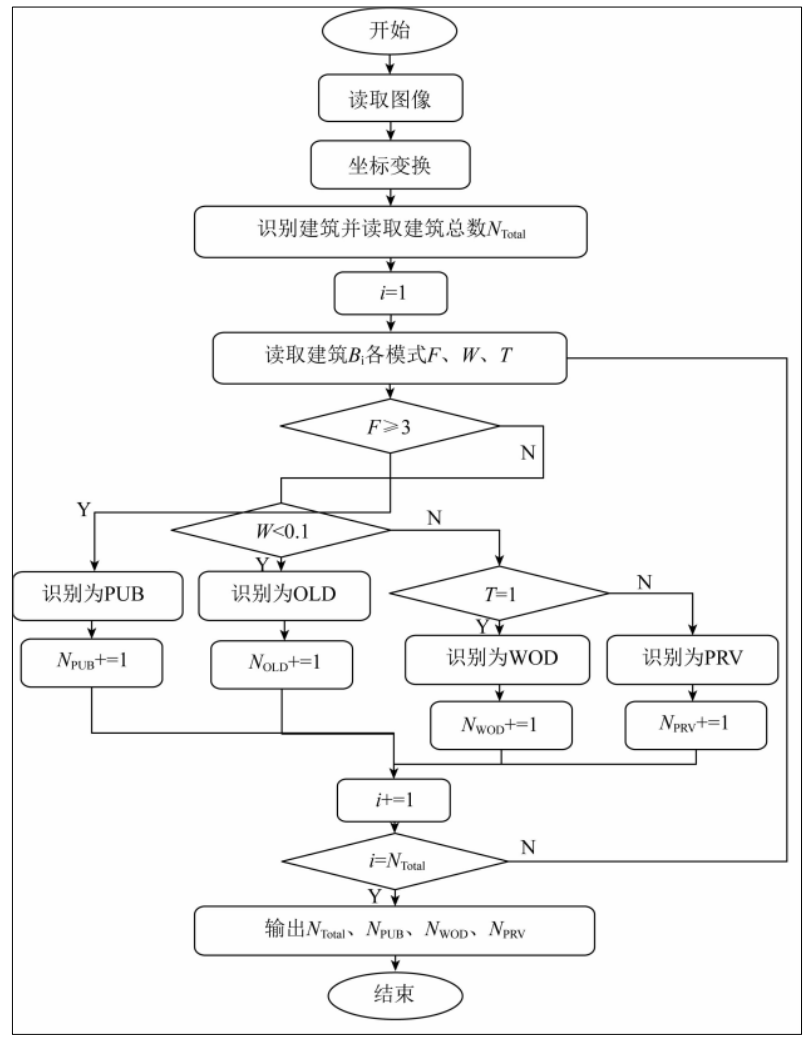

图 3 建筑图像模式识别流程图

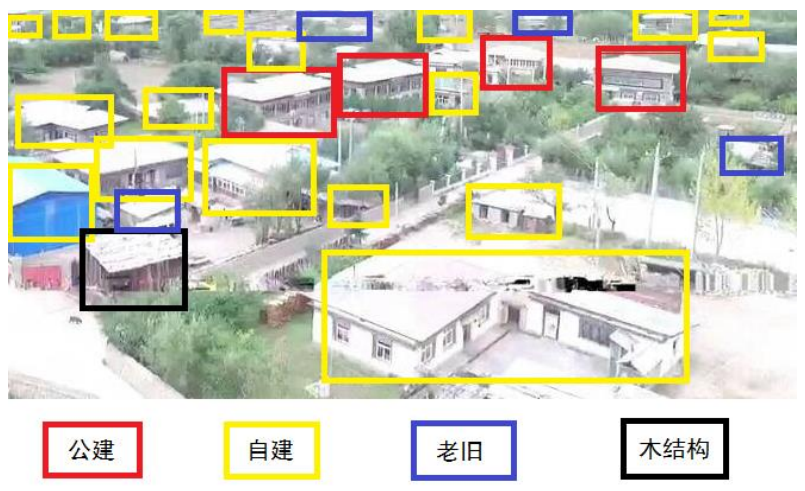

图 4 建筑图像模式识别示例

\section{5. 模式识别算法准确率分析}

第 4 节的模式识别算法的准确率如何, 需要实例 加以检验。本节选取了房屋数量较少的 4 张无人机 航班照片, 比较采用模式识别算法与人工统计方法 的结果, 分析模式识别算法的准确率。

4 张照片分别计为照片 1-4, 如图 5 所示。模式识 别和人工统计的各类型建筑的数量及准确率如表 1 所示。由表 1 可见, 本文的模式识别算法对公建房、 老旧房识别准确率较高, 木结构识别准确率稍低, 但总体对类型建筑数量的统计较准确。
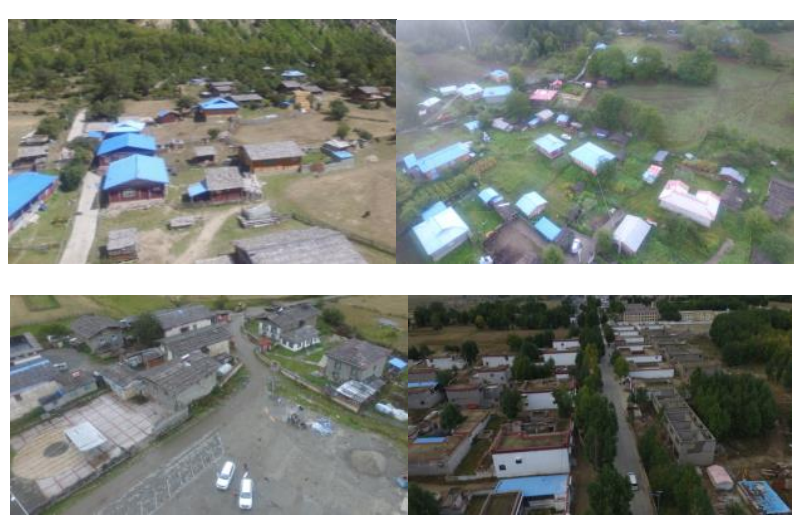

图 5 模式识别算法检验实例图。左上: 照片 1; 右上: 照 片 2; 左下: 照片 3; 右下: 照片 4

表 1 模式识别与人工统计建筑数量统计表 (幢)

\begin{tabular}{|c|c|c|c|c|c|c|c|c|}
\hline 建筑类 & \multicolumn{2}{|c|}{ 照片 1} & \multicolumn{2}{|c|}{ 照片 2} & \multicolumn{2}{|c|}{ 照片 3} & \multicolumn{2}{|c|}{ 照片 4} \\
\hline \multirow[t]{2}{*}{ Public } & $\begin{array}{l}\text { 模 } \\
\text { 式 }\end{array}$ & 0 & $\begin{array}{l}\text { 模 } \\
\text { ⿹弋工二 }\end{array}$ & 0 & 模 & 0 & $\begin{array}{l}\text { 模 } \\
\text { 式 }\end{array}$ & 4 \\
\hline & $\begin{array}{l}\text { 人 } \\
\text { 工 }\end{array}$ & 0 & $\begin{array}{l}\text { 人 } \\
\text { 工 }\end{array}$ & 0 & $\begin{array}{l}\text { 人 } \\
\text { 工 }\end{array}$ & 0 & $\begin{array}{l}\text { 人 } \\
\text { 工 }\end{array}$ & 4 \\
\hline \multirow[t]{2}{*}{ Private } & $\begin{array}{l}\text { 模 } \\
\text { 式 }\end{array}$ & 2 & $\begin{array}{l}\text { 模 } \\
\text { 式 }\end{array}$ & 3 & $\begin{array}{l}\text { 模 } \\
\text { 式 }\end{array}$ & 12 & $\begin{array}{l}\text { 模 } \\
\text { 式 }\end{array}$ & 30 \\
\hline & $\begin{array}{l}\text { 人 } \\
\text { 工 }\end{array}$ & 2 & $\begin{array}{l}\text { 人 } \\
\text { 工 }\end{array}$ & 1 & $\begin{array}{l}\text { 人 } \\
\text { 工 }\end{array}$ & 11 & $\begin{array}{l}\text { 人 } \\
\text { 工 }\end{array}$ & 30 \\
\hline \multirow[t]{2}{*}{ Old } & $\begin{array}{l}\text { 模 } \\
\text { 式 }\end{array}$ & 1 & $\begin{array}{l}\text { 模 } \\
\text { 式 }\end{array}$ & 1 & $\begin{array}{l}\text { 模 } \\
\text { 式 }\end{array}$ & 2 & $\begin{array}{l}\text { 模 } \\
\text { 式 }\end{array}$ & 2 \\
\hline & $\begin{array}{l}\text { 人 } \\
\text { 工 }\end{array}$ & 1 & $\begin{array}{l}\text { 人 } \\
\text { 工 }\end{array}$ & 1 & $\begin{array}{l}\text { 人 } \\
\text { 工 }\end{array}$ & 2 & $\begin{array}{l}\text { 人 } \\
\text { 工 }\end{array}$ & 2 \\
\hline \multirow[t]{2}{*}{ Wood } & $\begin{array}{l}\text { 模 } \\
\text { 式 }\end{array}$ & 16 & $\begin{array}{l}\text { 模 } \\
\text { 式 }\end{array}$ & 22 & $\begin{array}{l}\text { 模 } \\
\text { 式 }\end{array}$ & 5 & $\begin{array}{l}\text { 模 } \\
\text { 式 }\end{array}$ & 0 \\
\hline & $\begin{array}{l}\text { 人 } \\
\text { 工 }\end{array}$ & 17 & $\begin{array}{l}\text { 人 } \\
\text { 工 }\end{array}$ & 24 & $\begin{array}{l}\text { 人 } \\
\text { 工 }\end{array}$ & 4 & $\begin{array}{l}\text { 人 } \\
\text { 工 }\end{array}$ & 0 \\
\hline 准确率 & \multicolumn{2}{|c|}{$95 \%$} & \multicolumn{2}{|c|}{$96.2 \%$} & \multicolumn{2}{|c|}{$88.2 \%$} & \multicolumn{2}{|c|}{$100 \%$} \\
\hline
\end{tabular}

\section{6. 建筑暴露度统计}

使用本文的图像模式识别方法统计西藏东南部 三市各区县的各类型建筑分布, 如表 2 所示。

对第三节的四种建筑类型建立易损性模型。建立 方法主要基于西藏及周边地区近年来地震灾害的震 害统计资料, 如 2010 年青海玉树地震 M7. 级地震 ${ }^{6-}$ 9], 2015 年尼泊尔 Mw7.8 级地震 ${ }^{[10-14] 、 2017 ~}$ 年西藏 米林 M6.9 级地震等。玉树地震、尼泊尔地震的典型 震害图片如图 6 所示。 
表 2 各县各类型建筑总数统计表

\begin{tabular}{|c|c|c|c|c|c|c|c|c|c|}
\hline 坆市 & 区县 & 公建方 & 自建新房 & 老明房 & 木结秋 & 公建房人口 & 自建锤的人口 & 老旧房人口 & 小结楀人口 \\
\hline \multirow{8}{*}{ 拉萨帥 } & 城关区 & 34960 & 25169 & 6187 & 0 & 147120 & 105917 & 26036 & 0 \\
\hline & 埧在锚戻区 & 1144 & 3443 & 4753 & 0 & 6400 & 19261 & 26589 & 0 \\
\hline & 林周县 & 777 & 3442 & 4913 & 。 & 5956 & 26384 & 37660 & 0 \\
\hline & 当却具 & 599 & 2683 & 3834 & 0 & 3911 & 17518 & 25034 & 0 \\
\hline & 尼木县 & 428 & 1911 & 2730 & 0 & 2874 & 12835 & 18335 & 0 \\
\hline & 曲水县 & 562 & 2518 & 3596 & 0 & 2682 & 12017 & 17161 & 0 \\
\hline & 达改县 & 456 & 2045 & 2921 & 0 & 2452 & 10995 & 15705 & 0 \\
\hline & 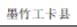 & 643 & 2879 & 4112 & 0 & 3763 & 16848 & 24063 & 0 \\
\hline \multirow{12}{*}{ 山南市 } & 乃东区 & 6882 & 6267 & 2634 & 0 & 27519 & 25060 & 10532 & 0 \\
\hline & 扎霜具 & 542 & 2693 & 3872 & 0 & 3051 & 15157 & 21793 & 0 \\
\hline & 兵喛县 & 942 & 3516 & 4953 & 0 & 5005 & 18680 & 26315 & 0 \\
\hline & 雪目是 & 337 & 1670 & 2402 & 0 & 1319 & 6538 & 9404 & 0 \\
\hline & 琼帮且 & 309 & 1538 & 2210 & 0 & 1432 & 7130 & 10245 & 0 \\
\hline & 曲粉县 & 451 & 1384 & 1915 & 。 & 1961 & 6019 & 8328 & 0 \\
\hline & 捍关县 & 246 & 1221 & 1755 & 0 & 1069 & 5305 & 7626 & 0 \\
\hline & 常扎旦 & 338 & 1681 & 2420 & 0 & 1523 & 7574 & 10903 & 0 \\
\hline & 加在县 & 422 & 2696 & 3733 & 0 & 1331 & 8503 & 11774 & 0 \\
\hline & 绦子旦 & 602 & 2991 & 4302 & 0 & 2688 & 13354 & 19207 & 0 \\
\hline & 解那县 & 316 & 1572 & 2260 & 0 & 1164 & 5790 & 8324 & 0 \\
\hline & 泿有子且 & 502 & 2494 & 3587 & 0 & 2651 & 13172 & 18944 & 0 \\
\hline \multirow{7}{*}{ 林芝市 } & 巴宜保 & 5421 & 4337 & 1429 & 0 & 32467 & 25975 & 8558 & 0 \\
\hline & 工有江达且 & 736 & 2748 & 3872 & 0 & 2755 & 10285 & 14492 & 0 \\
\hline & 米林县 & 809 & 768 & 1125 & 1643 & 4282 & 4065 & 5955 & 8697 \\
\hline & 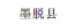 & 298 & 310 & 474 & 707 & 2339 & 2433 & 3720 & 5549 \\
\hline & 旅蜜县 & 907 & 949 & 1457 & 2176 & 5122 & 5360 & 8229 & 12289 \\
\hline & 察胜旦 & 815 & 855 & 1316 & 1965 & 5342 & 5604 & 8625 & 12879 \\
\hline & 明县 & 360 & 1320 & 1857 & 0 & 1530 & 5612 & 7895 & 0 \\
\hline
\end{tabular}
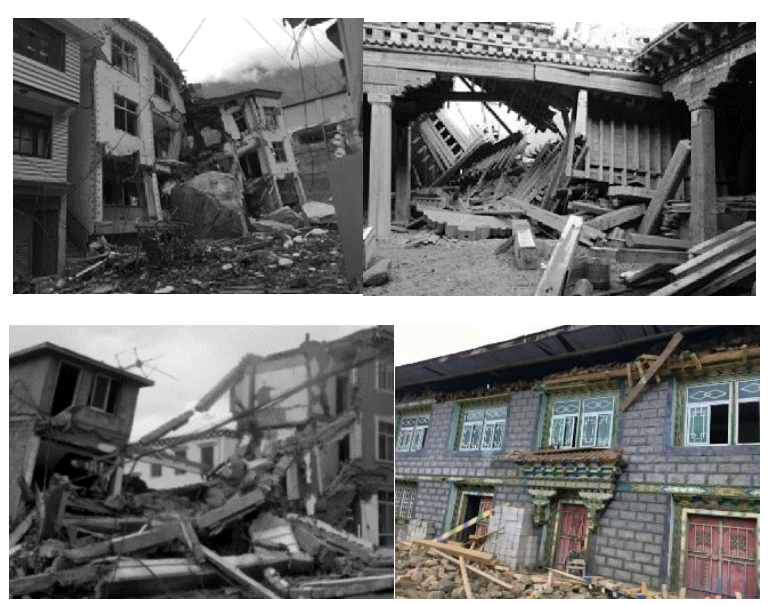

图 6 震害统计图片。上左: 尼泊尔地震后的西藏樟木, 烈 度 8 度; 上右: 尼泊尔地震后的西藏吉隆, 烈度 8 度; 下 左: 玉树地震后的结古镇, 烈度 9 度; 下右: 米林地震后 的林芝市, 烈度 7 度。图片来源: 高锦瑞等 (2015) ; 白 国良等（2011）；曲哲，杨永强（2015）

为分别计算地震造成的经济损失和人员伤亡, 本 文对结构和人口都建立了易损性模型。四种建筑类 型的结构和人口易损性曲线如图 7 所示。其中 $\mathrm{PGA}<0.6 \mathrm{~g}$ 区间的损失率的标准差为 0.3 , 其余区间 标准差为 0.1 。

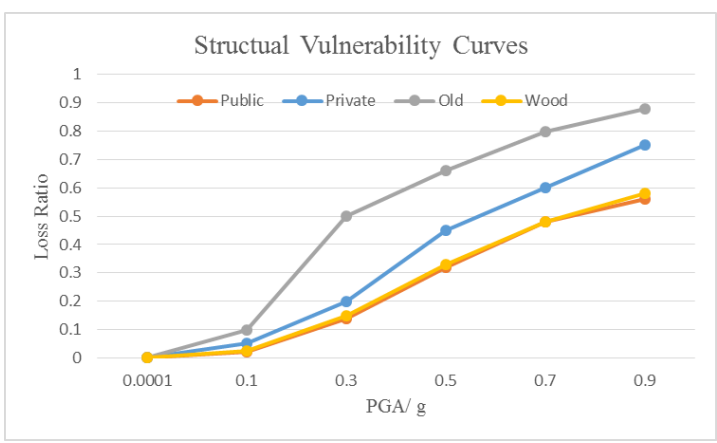

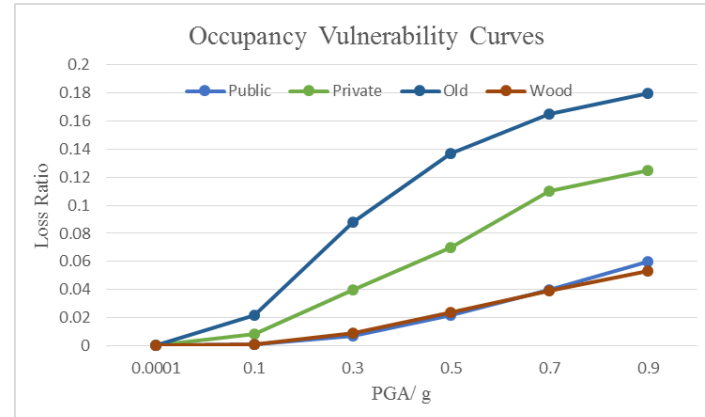

图 7 四种类型建筑的易损性曲线, 上: 结构易损性; 下: 人口易损性

\section{7. 设定地震的模型检验}

2017 年 11 月 18 日林芝米林发生了 6.9 级地震。 模拟米林地震并产出震后损失分布图, 与实际震害 比较, 能够在一定程度上验证本文承灾体模型和易 损性模型的可靠性。因此本文模拟了该次地震的地 震动分布, 并计算了西藏东南部可能遭受的人员伤 亡分布。

设定地震使用的断层参数如表 3 所示。发震断层 设为一条与雅鲁藏布江断裂共轭的 NW-SE 走向断裂。 震级-破裂尺度的经验关系使用 Wells 和 Coppersmith (1994) [15]提出的关系, 地震动衰减关系使用俞言 祥等 (2013) [16]对中国地震动参数区划图使用的衰 减关系。模拟出的地震动分布如图 8 所示。

表 3 模拟米林地震的断层参数

\begin{tabular}{|c|c|c|c|c|c|}
\hline 震级 & $\begin{array}{c}\text { 震中位 } \\
\text { 置 }\end{array}$ & $\begin{array}{c}\text { 走向 } \\
\left({ }^{\circ}\right)\end{array}$ & $\begin{array}{c}\text { 倾角 } \\
\left({ }^{\circ}\right)\end{array}$ & $\begin{array}{c}\text { 滑动 } \\
\text { 角 }\left({ }^{\circ}\right. \\
)\end{array}$ & $\begin{array}{c}\text { 震源深 } \\
\begin{array}{c}\text { 度 } \\
\mathrm{km})\end{array}\end{array}$ \\
\hline 6.9 & $\begin{array}{c}95.02 \mathrm{E}, \\
29.75 \mathrm{~N}\end{array}$ & 120 & 45 & 60 & 20 \\
\hline \multicolumn{3}{|c|}{ Ground Motion Fields of M6.9 Earthquake } \\
\hline
\end{tabular}

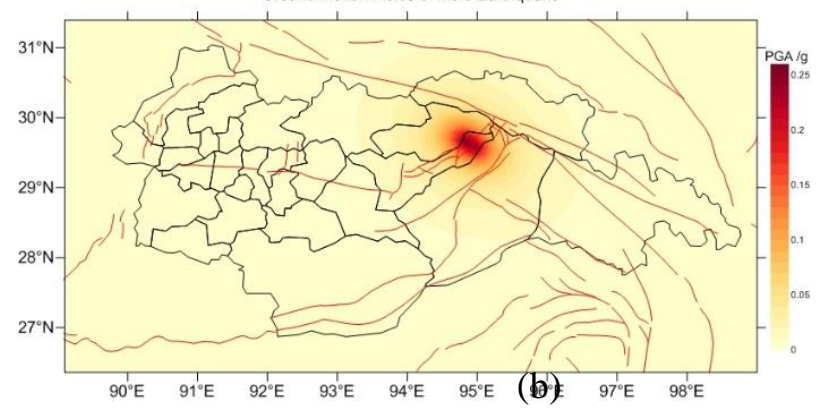

图 8 模拟米林 6.9 级地震的地震动影响场

根据地震动影响场、承灾体规模模型和易损性模 型, 计算曲松-桑日地震在西藏东南部各县造成的建 筑物轻度以上破坏数量和人员伤亡分布, 如表 4 所 示。可见, 模拟的米林地震可能造成的建筑物轻度 以上破坏数量总数约 6600 间, 人员伤亡总数约 50 人, 其中林芝市损失最重。 
表 4 模拟米林 6.9 级地震造成各县人员伤亡列表

\begin{tabular}{cccc}
\hline 名次 & 区县 & $\begin{array}{c}\text { 轻度以上破 } \\
\text { 坏房屋 }\end{array}$ & 伤亡 \\
\hline 1 & 林芝 & 3352 & 30 \\
2 & 米林 & 1407 & 15 \\
3 & 工布江达 & 839 & 6 \\
4 & 加查 & 573 & 4 \\
5 & 波密 & 325 & 2 \\
6 & 朗县 & 63 & 1 \\
7 & 墨脱 & 42 & 1 \\
合计 & & 6601 & 59
\end{tabular}

2017 年米林 6.9 级地震的实际震害为房屋受损 7800 余间, 2 人受伤。可见本文的建筑损失的模拟 结果比实际震害偏轻, 人员伤亡的模拟结果比实际 震害偏重, 但总体误差在合理范围内。

\section{8. 基于地震危险性的地震风险分析}

本节基于西藏东南部的地震危险性资料估算未来 50 年可能遭受的地震财产损失分布。地震危险性的 资料来源于 《中国地震动参数区划图 (GB183062015）》[17]。西藏东南部地震危险性图如图 9 所示。

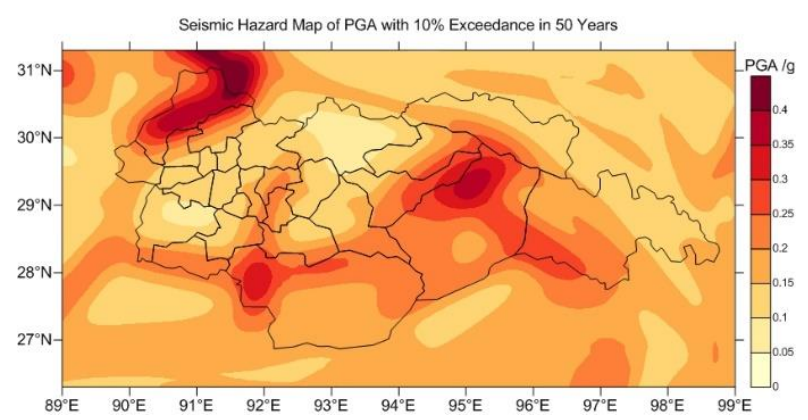

图 9 西藏东南部地震危险性图

使用基于蒙特卡洛的地震危险性计算方法 ${ }^{[18]}$ 生成 50 年的随机地震目录, 对每次地震计算个各县的损 失情况, 再计算出 50 年的总损失。各县的 50 年超越 概率 $10 \%$ 的损失分布情况如图 10 所示。经济损失风 险最高的 10 个县的列表如表 5 所示。可见，未来 50 年财产损失风险最高的地区是拉萨市区、林芝市区 和错那县, 超越概率 $10 \%$ 的损失可能超过 6 亿元。 其中拉萨市区可能超过 20 亿元。

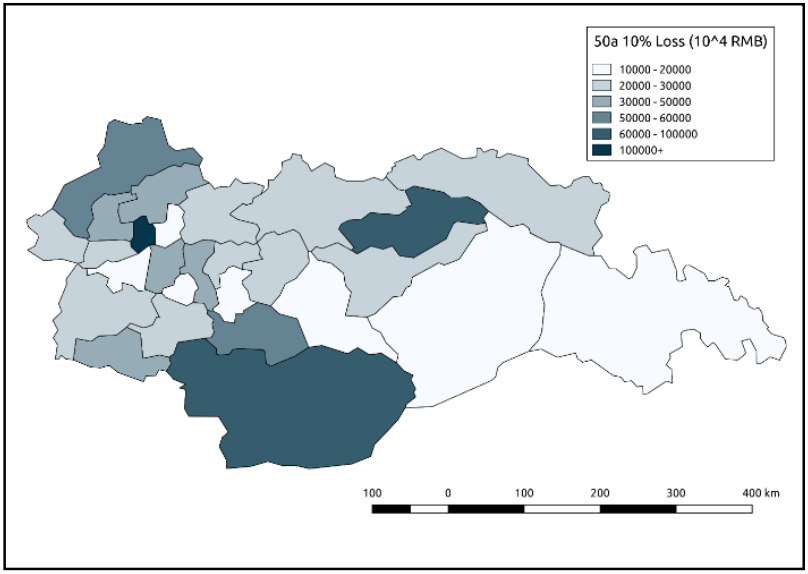

图 10 西藏东南部各县 50 年超越概率 $10 \%$ 的财产损失分布 图

表 5 西藏东南部地震财产损失风险最高的 10 个县列表

\begin{tabular}{ccc}
\hline 名次 & 区县 & 损失 $($ 万元) \\
\hline 1 & 城关区 & 203800 \\
2 & 巴宜区 & 65610 \\
3 & 错那 & 64410 \\
4 & 当雄 & 53020 \\
5 & 隆子 & 52300 \\
6 & 扎囊 & 41020 \\
7 & 洛扎 & 37530 \\
8 & 乃东 & 36220 \\
9 & 林周 & 32090 \\
10 & 堆龙德庆 & 31900 \\
\hline
\end{tabular}

\section{9. 结论和讨论}

本文使用西藏东南部的人口和建筑结构类型资料, 用估算的方法建立了人口和建筑的承灾体模型, 根 据藏式建筑结构在历史地震中的震害资料建立了各 类型建筑的结构易损性和人口易损性模型，并对西 藏东南部的地震人员伤亡和建筑经济损失风险进行 了评估。得出的结论主要有:

(1) 西藏东南部的公建房和木结构房抗震性能较 好, 自建新房有一定抗震能力, 老旧房抗震性能较 差。

(2) 本文的米林 6.9 级地震建筑损失模拟结果比实 际震害偏轻, 人员伤亡模拟结果比实际伤亡偏重, 但总体误差在合理范围内, 证明了本文模型的合理 性。

(3) 西藏东南部未来 50 年建筑地震风险最高的地 区是拉萨市区、林芝市区和错那县, 其中拉萨市区 的建筑财产损失风险最高。

(4) 本文使用的三维图像模式识别方法在数秒内 识别了 1000 余幢建筑物的模式特征, 效率远高于人 
工识别, 根据识别结果建立的承灾体模型结果模拟 地震震害的检验, 说明了该 AI 技术在对西藏东南部 建筑图像分类与识别中的有效性。

\section{致谢}

本文资料收集及撰写过程中，得到了以下单位 和个人的大力支持和无私帮助，在此特别表示感谢： 西藏自治区政府、西藏地震局、拉萨市城关区娘热 乡政府、娘热乡加尔西村支部、堆龙德庆区桑木村 支部、山南市地震局、林芝市地震局。本文计算地 震风险使用的是全球地震模型（GEM）基金会开发的 OpenQuake 软件 ${ }^{[19]}$ 。2017 年西藏米林 Ms6. 9 级地震的 震害资料来自网络和中国地震局地震应急救援队。 本文由中国地震局地球物理研究所基本科研业务费 专项（DQJB17T04）资助。

\section{参考文献}

[1]李小涛. 2004. 地统计学和神经网络在遥感影像分 类中的应用研究. 济南: 山东科技大学硕士学位论文.

[2] 李燕, 陈荣, 董秀兰等. 2012. 基于神经网络的遥感 图像识别算法. 测绘与空间地理信息, 35(2): 156-158.

[3] 侯舒维, 孙文方, 郑小松. 2014. 遥感图像云检测方 法综述. 空间电子技术, 11(3): 68-76, +86 .

[4] Li C L, Gao M T. 2019. Seismic Hazard Model Harmonization in Tienshan Area. Journal of Risk Analysis and Crisis Response, 9(2): 74-84.

[5] 国务院人口普查办公室委员会, 国家统计局人口 和就业统计司. 2010. 中国 2010 年人口普查资料. 北京 : 中国统计出版社.

[6] 谭明, 李洋, 胡伟华等. 2010. 青海玉树 7. 1 级地震 房屋建筑震害调查和分析. 内陆地震, 24(2): 173-179.

[7] 秦松涛, 李智敏, 谭明, 等. 2010. 青海玉树 7. 1 级地 震震害特点分析及启示. 灾害学, 25(3): 65-70.

[8] 黄思凝, 袁一凡, 孟庆利, 等. 2011. 由玉树地震结构 震害看村镇房屋抗震. 世界地震工程, 27(2): 77-82.

[9] 白国良, 薛冯, 徐亚洲. 2011. 青海玉树地震村镇建 筑震害分析及减灾措施. 西安建筑科技大学学学报 (自然科学版), 43(3): 309-315.

[10] 高锦瑞, 尼玛, 文升梁, 等. 2015. 尼泊尔 8.1 级地 震对中国西藏地区造成的震害特征分析. 震灾防御技 术, 10(4): 961-一968.

[11] 王晓青, 黄树松, 丁香等. 2015. 尼泊尔 8.1 级地震 建筑物震害遥感提取与分析. 震灾防御技术, 10(3): 481-490.

[12] 曲哲, 杨永强. 2015. 尼泊尔自建民居在 2015 年地 震序列中的震害. 地震工程与工程振动, 35(4): 51-59.
[13] 张昊宇, 王涛, 林旭川等. 2016. 尼泊尔 8.1 级地震 钢筋混凝土框架典型震害及讨论. 工程力学, 33(9): 59-68.

[14] 潘毅, 王忠凯, 时胜杰, 等. 2017. 尼泊尔 8. 1 级地 震加德满都一樟木沿线民居震害调查与分析. 湖南大 学学报(自然科学版), 44(3): 35-44.

[15] Wells D L, Coppersmith K J. 1994. New empirical relationships among magnitude, rupture length, rupture width, rupture area, and surface displacement. Bulletin of the Seismological Society of America, 84(4): 974-1002.

[16] 俞言祥, 李山有, 肖亮. 2013. 为新区划图编制 所建立的地震动衰减关系. 震灾防御技术, 8(1): 2433.

[17] 中华人民共和国国家质量监督检验检疫总局, 中 国国家标准化管理委员会. 2015. GB 18306-2015 中国 地震动参数区划图. 北京: 中国标准出版社.

[18] Ebel J E, Kafka A L. 1999. A Monte Carlo approach to seismic hazard analysis. Bulletin of the Seismological Society of America, 89(4): 854-866

[19] Pagani M, Monelli D, Weatherill G. 2014. OpenQuake Engine: An Open Hazard (and Risk) Software for the Global Earthquake Model. Seismological Research Letters, 85(3): 692-702. 